\title{
Excessive bird collecting in Malawi: a new threat
}

\author{
FRANCOISE DOWSETT-LEMAIRE, JOHN G. M. WILSON, \\ ROBERT D. MEDLAND and LIZANNE ROXBURGH
}

\section{Summary}

Malawi is under heavy pressure for land by an increasing human population, and there is little natural habitat left outside gazetted wildlife and forest reserves. Widespread collecting of birds in Malawi's small protected rain forests by the National Museum of Malawi in conjunction with Western academic institutions has been taking place almost yearly since 2001 and has continued until at least 2011. The collection of specimens, although often a contentious issue, does have scientific value but should be undertaken in a limited way with careful evaluation of the populations from which birds are being taken. We consider that the numbers collected are likely to pose a threat to some bird populations in view of their isolation and the slow turn-over rates of breeding individuals. Collecting has been carried out in some of the same reserves two or three times within a few years. Examples are given of very small populations in Malawi and adjacent Mozambique where the slightest off-take would be very dangerous. Many species have been collected during their breeding season, which we find both wasteful and unethical. Several of the species collected occur in no more than one or two reserves today in Malawi and in such instances we recommend their complete protection. We are also concerned about the example presented to the local communities, reserve wardens and young conservation biologists by the off-take of hundreds of birds in official reserves which were primarily set up for the protection of wildlife.

\section{Résumé}

Le Malawi subit une forte pression démographique, et il reste peu de milieux naturels en dehors des réserves de faune et réserves forestières. D'importantes récoltes d'oiseaux dans plusieurs des petites forêts ombrophiles protégées ont été obtenues presque chaque année depuis 2001, et ces activités se sont poursuivies au moins jusqu'en 2011. Le fait que le Musée National du Malawi est impliqué de concert avec des institutions académiques occidentales pose de nombreuses questions d'ordre éthique et environnemental. Nous ne mettons pas en doute l'intérêt scientifique des recherches entreprises et ne sommes pas opposés en principe à l'obtention d'un petit nombre de spécimens pour autant que les populations puissent le supporter, mais nous considérons que les nombres obtenus posent une menace pour la survie des populations d'oiseaux en raison de leur isolement et du faible taux de renouvellement des individus. Certaines réserves ont été visitées deux ou trois fois par les récolteurs sur quelques années. Nous citons plusieurs exemples de très petites populations isolées au Malawi et au Mozambique voisin où le moindre prélèvement serait très dangereux. Beaucoup d'espèces ont été récoltées pendant leur période de reproduction, ce que nous considérons comme du gaspillage immoral. Plusieurs des espèces récoltées ne se trouvent plus au Malawi que dans une ou deux réserves, et dans ce cas nous pensons qu'elles devraient recevoir une protection totale. Enfin, nous nous interrogeons sur l'exemple offert par ces pratiques de récoltes intensives pour les communautés locales, les gardes de faune, et les étudiants en biologie de la conservation, alors que justement les réserves en question ont été constituées pour protéger la biodiversité. 


\section{Introduction}

Malawi is a small, landlocked country, with a high human population density and an economy based on agriculture. Population pressure on natural habitats is increasing to such an extent that there is now very little natural vegetation outside gazetted wildlife and forest reserves. The primary function of both types of reserves, as stated in the Malawian Wildlife Act of 1992 and Forestry Act of 1997, is to protect habitats and conserve and enhance biodiversity. In practice the integrity of forest reserves is not always respected, especially in the more heavily-populated south; some of this is due to poor management practices and short-term political gains. The demise of one of the more important forest reserves (>1,00o ha) on Thyolo Mountain in the late 1990 is an example of short-sighted destruction that benefited no-one, while an immense scientific heritage was lost (Dowsett-Lemaire et al. 2001, Dowsett-Lemaire and Dowsett 2006: 82). Several smaller forest reserves have suffered the same fate, although wildlife reserves on the whole are better protected.

The avifauna of Malawi is relatively well known: in the 19th and early 2oth century bird specimens were collected all over the country, and there are in excess of 16,500 specimens, of which 7,500 are in the Natural History Museum, UK (Benson and Benson 1977: 220-221). Other important collections have been deposited in African museums (e.g. Blantyre, Bulawayo, Pretoria, Durban, Livingstone) and North American institutions (Toronto, Washington, Pittsburgh, Harvard etc.). Wide-ranging field surveys, by both professionals and amateurs, were carried out in the 1980s until the early 2000s, and this culminated in the production of a comprehensive atlas and handbook (Dowsett-Lemaire and Dowsett 2006). The authors were especially interested in forest birds and undertook investigations into the breeding ecology and population dynamics of montane species over several years (e.g. Dowsett 1985, Dowsett-Lemaire 1985, 1989a).

In 2001 a new wave of bird collecting started, targeting in particular forest species normally protected in forest and wildlife reserves. One of the principal aims of this exercise is said to be studies of avian parasites and molecular genetics but the scale of the collecting seems to have been out of proportion to the scientific needs of such investigations. In this paper we wish to draw attention to a problem that had not perhaps been considered or publicised as a threat to bird conservation in Africa so far, i.e. the collecting of disproportionately large numbers of birds in isolated habitat reserves, some of them being quite small or having rather small populations of certain species. We use here the nomenclature of Dowsett-Lemaire and Dowsett (2006).

\section{The data}

Details of birds collected in Malawi by the Field Museum of Natural History (FMNH, Chicago) were obtained from two sources. First, details of birds collected between 2003 and 2005 were downloaded from the museum's website (http://www.fieldmuseum.org/research_collections/ zoology/collections_birds.htm). Additionally, details of the collections covering the years 2001 to 2011 were downloaded from The Global Biodiversity Information Facility (GBIF). Altogether, some 5,379 specimens are reported. For 2001, only small numbers are listed (241, from forest reserves in the south, including Zomba, Phirilongwe and Mount Mulanje). Otherwise collections came from the following reserves:

- Misuku Hills Forest Reserve (the majority from Mugesse Forest, 720 ha in size), with 1,214 specimens (544 in October-November 2003 and 670 in June-July 2007);

- Nyika National Park, with 1,156 specimens (771 in June-July 2004 and 385 in OctoberNovember 2009);

- Vwaza Marsh Wildlife Reserve, with 406 specimens (October-November 2009);

- Ntchisi Forest Reserve (with 250 ha of rain forest), 375 specimens (355 taken in SeptemberOctober 2005, the remaining 20 in October 2007); 
- Nkhotakota Wildlife Reserve (including the 44-ha patch of forest on Chipata Mountain), with 388 specimens in September-October 2007;

- Chongoni Forest Reserve (with 180 ha of forest), 200 specimens in September 2005, and smaller numbers in Dzalanyama Forest Reserve and Mafinga Hills Forest Reserve.

- Namizimu and Mangochi Mountain Forest Reserves, with 452 specimens in FebruaryMarch 2011;

- Mount Mulanje Forest Reserve, with 868 specimens in June-July 2006 (and a minimum of 96 in November 2001).

In addition to the FMNH expeditions, further collections were undertaken in the Nyika National Park in 2007 by national and other American collectors, for which we have no details. Hundreds of birds were taken (tour guide Abassi Jana pers. comm. to David Foot in litt. 2008 to FDL], then manager of the Nyika-Vwaza Conservation Trust). There was further collecting also on Mulanje in November-December 2007: on 8 and 1o November, RDM met a professor and his students from a California university, along with National Museum staff, demonstrating the preparation of skins in the upper Likhabula Valley. They had been collecting with mist-nets and a shotgun for about a week. During discussions with RDM the university staff admitted that a proportion of birds collected by shooting were unusable owing to damage from gunshot.

Collecting (including with a shotgun) continued in December, when the National Museum was involved (information provided by guides to the manager of Likhabula tourist centre). Tourists mentioned to David Nangoma (Mount Mulanje Conservation Trust) that museum technicians were collecting "hundreds of birds indiscriminately".

Numbers of birds collected by the FMNH are minimum figures as we do not know how many more specimens were collected independently by the National Museum. Examples include:

- 199 Starred Robins Pogonocichla stellata, of which 55 were taken from Mugesse in one visit (2003), and 37 from Ntchisi;

- 375 Andropadus greenbuls, identified to species only in 2003-2005, i.e. 79 Little Greenbuls Andropadus virens ( 38 from the Misuku Hills in 2003 and 31 from Ntchisi in 2005), 57 Eastern Mountain Greenbuls Andropadus nigriceps from the Nyika National Park in a single visit (2004), and 53 Stripe-cheeked Greenbuls Andropadus milanjensis (including 26 from the Misuku Hills in 2003 and 23 from Ntchisi in 2005);

- 154 Olive Sunbirds Nectarinia olivacea, with 54 from the Misuku Hills alone;

- 103 Cabanis's (Placid) Greenbuls Phyllastrephus cabanisi, including 55 from the Misuku Hills (of which 44 were taken in one visit, 2007);

- 105 Red-faced Crimsonwings Cryptospiza reichenovii, of which 53 came from the Misuku Hills in a single visit (2007);

- 102 Red-throated Twinspots Hypargos niveoguttatus, of which 31 came from one site (Likhabula) at Mulanje;

- 88 Yellow White-eyes Zosterops senegalensis, with 71 from the Nyika National Park;

- 43 Yellow-streaked Greenbuls Phyllastrephus flavostriatus of the montane race alfredi, including 30 from Ntchisi (at southern limit of range) in one visit;

- 52 Forest Batises Batis mixta (all from the Misuku Hills, at southern limit of range);

- 71 Malawi (Cape) Batises Batis (capensis) dimorpha, with 46 from the Nyika;

- 43 Cinnamon Bracken Warblers Bradypterus cinnamomeus, with 37 from the Nyika;

- 31 Churring Cisticolas Cisticola njombe (all from the Nyika, at southern limit of range);

- 28 Greater Double-collared Sunbirds Nectarinia afra of the race whytei from the Nyika.

Table $\mathrm{S}_{1}$ in the online supplementary material lists the bird specimens collected in Malawi by the FMNH between 2001 and 2011. 


\section{Reasons for concern}

\section{Globally or nationally threatened species}

Three of the species taken are listed as threatened or Near Threatened on the IUCN Red List (BirdLife International 2008): a Blue Swallow Hirundo atrocaerulea was collected in the Nyika National Park in 2009, a breeding female Olive-headed Weaver Ploceus olivaceiceps at Ntchisi in 2005 (and one bird from Namizimu) and 21 Yellow-breasted Apalis Apalis (thoracica) flavigularis were collected on Mount Zomba (six individuals) in 2001 and Mount Mulanje ( 15 individuals) in 2006. Green Barbet Stactolaema olivacea and Silvery-cheeked Hornbill Bycanistes brevis are considered nationally threatened, and the collecting of what may seem moderate numbers ( 12 and eight respectively) could have a damaging effect on local populations. The former has been exterminated in the south, following the destruction of Thyolo Forest, and the Misuku Hills, where all the specimens were taken, are the last stronghold of the species in Malawi. The Silvery-cheeked Hornbill has been decreasing fast in southern Malawi following widespread deforestation, from Mulanje to the Malawi Hills, and the main population today is also in the Misuku Hills (DowsettLemaire and Dowsett 2006), where six out of eight specimens were taken.

Eleven White-winged Starlings Neocichla gutturalis were collected in Vwaza Marsh Wildlife Reserve in 2009: this species has a very small, disjunct range in the Zambezian region (Fry et al. 2000) and in Malawi is now strictly confined to Vwaza Marsh, following habitat destruction around the reserve. African Pitta Pitta angolensis, collected there during the breeding season, is highly threatened in Malawi, with very few potential or actual nest sites remaining (DowsettLemaire and Dowsett 2006). The populations of all these species in Malawi are very small and they deserve protection.

\section{Numbers taken}

Numbers of many species taken are far in excess of what is needed for current studies of DNA, especially as much valuable information can also be obtained from fresh blood samples taken from live birds that can be released unharmed (Melo and Fuchs 2008), or from museum material already available. However, the study of internal parasites may require more specimens, and this is perhaps what is behind some of the largest numbers of birds taken. If so, it is unfortunate that the small isolated populations of montane birds in Malawi were selected for such a study, especially without prior analysis of the populations involved and their potential resilience to the removal of large percentages. The figures shown above appear to us to pose a threat to the survival of bird populations for two main reasons:

\section{Isolation of populations}

Details of the distribution of bird species in Malawi as given below can be found in DowsettLemaire and Dowsett (2006) and references therein. Some of the species collected have very small ranges or occur in a series of isolated patches of suitable habitat on the top of mountains. Examples include Eastern Mountain Greenbul, found in Malawi only on the highest mountains, from the Mafinga Hills to the Viphya Plateaux in the north, and on Mulanje and Zomba Mountains in the south. Cinnamon Bracken Warbler is another high montane endemic reaching its southern range limit in Malawi, with just two populations on the Nyika Plateau and on Mount Mulanje. Churring Cisticola is a range-restricted species (Stattersfield et al. 1998), limited to montane grassland in south-west Tanzania and northern Malawi: in Malawi it is confined to the Nyika Plateau, while some of its habitat in Tanzania is threatened by exotic plantations of pine and eucalyptus (N. Baker in litt. 2010). The race whytei of Greater Double-collared Sunbird is strictly endemic to the Nyika Plateau. The montane race alfredi of Yellow-streaked Greenbul is confined to montane forest in south-west Tanzania and northern Malawi, reaching its southern limit of range on Ntchisi Mountain. The forest on Ntchisi is both small and very isolated, being $150 \mathrm{~km}$ south of 
the nearest population of greenbuls on the South Viphya (Kawandama). In Malawi, Forest Batis occurs only in the Misuku Hills.

While some of these birds may be locally common, repeated visits to the same areas may have resulted in numbers taken that are incompatible with the maintenance of a healthy population. More collecting of hundreds of birds was carried out in the Misuku Hills in 2007 after hundreds had already been taken in 2003, and the second collecting expedition to the Nyika National Park targeted at least some of the same areas and species, since several White-chested Alethe Alethe fuelleborni were taken from Zovochipolo forest patches in 2007 (Abassi Jana pers. comm. to D. Foot in litt. to FDL), a species that had already been collected (five specimens) in the same area in 2004 .

One of our major concerns is that isolated populations of birds can be so small as to be threatened with extirpation by even the smallest off-take. Olive Thrush Turdus olivaceus is an example of a species which is very rare on some mountains in Malawi and elsewhere. A recent survey of Namuli Mountain, in adjacent Mozambique, revealed the presence of very few birds localized on Muretha Plateau (Dowsett-Lemaire 2010). One very vocal, unmated male was under watch for the whole duration of the expedition and was still unmated when FDL left this location after nine days. This was in the middle of the breeding season (November) and suggests that a surplus of non-breeding floaters is very limited or non-existent. The collection of one of only two pairs present on Muretha Plateau by another member of the expedition was certainly a mistake - this happened before FDL had time to assess population figures and advise against this. Another example is Namuli Apalis Apalis (thoracica) lynesi, long considered endemic to Namuli Mountain, until it was discovered in 2008 on Mabu Mountain (Dowsett-Lemaire 2010). Despite the large size of Mabu Forest $\left(60-70 \mathrm{~km}^{2}\right)$, the apalis is extremely rare there, being confined to altitudes above $1,400 \mathrm{~m}$. In nearly three weeks of surveys, only four birds were found: one pair and two unmated males. Again, this suggests that floaters may be nonexistent, and that, for some reason, the conditions of the forest there were not optimal for the species. At lower altitudes in the Shire Valley of Malawi, habitat loss outside reserves has reduced the populations of some species to such an extent that they are now at risk of extinction through isolation, e.g. Gorgeous Bush Shrike Malaconotus viridis and Black-and-white Flycatcher Bias musicus, which are now confined to small areas of dry forest and thickets in Lengwe National Park. Of the latter, no more than three pairs could be located in extensive surveys in 2001-2002.

Collecting large or even moderate numbers of birds at the limit of their range can be particularly damaging (e.g. Forest Batis in the Misukus, Yellow-streaked Greenbul of the race alfredi at Ntchisi). A large number of greenbuls were collected at Ntchisi in 2005 and the species was said to be still common when the forest was revisited by J. Bates in 2009 (J. Bates in litt. to an anonymous correspondent in litt. to FDL via N. Baker 2010): this requires verification. We argue that, when planning to collect a large number of birds, best practice should be to check population sizes before deciding to collect such a large number rather than after. No-one has studied the densities of this greenbul in detail on Ntchisi, but on the Nyika Plateau, where it is considered common, densities are 3-4 pairs/ Io ha (Dowsett-Lemaire 1989a); this at least suggests an order of magnitude for Ntchisi.

We can give at least one example in Malawi of the negative impact of collecting. In October 1972, R. J. Dowsett collected II African Hill Babblers Pseudoalcippe abyssinica in the forest on Mangochi Mountain, south-east Malawi; Mangochi is at the southern limit of the bird's range. The forest covers 230 ha (comparable to the size of Ntchisi Forest), and the bird was considered common (Dowsett and Hunter 1980). On a visit in October 1983, FDL spent several days trying to assess densities of forest birds and was unable to find more than two, or perhaps three, occupied territories of Hill Babbler in the whole of the forest, all of these being confined to a small section of taller canopy forest in the centre. The forest had not decreased in size and it was unlikely that climatic conditions had changed much in II years: thus, it would appear that the taking of II adults in the breeding season proved too much for the local population, although this may not appear to be an excessive number to many collectors.

Very little work has been done in Africa on the ability of montane forest birds to re-colonise small patches of forest from which they have been eliminated. The example of African Hill Babbler above suggests that re-colonisation from elsewhere did not happen; the nearest population to the north is on Namizimu, $55 \mathrm{~km}$ distant. Even in an area with numerous forest patches within 
short distances of each other, as on the Nyika Plateau, mobility may be limited in some species, or there may be a dearth of floating non-breeding individuals locally. In this respect, translocation experiments that R. J. Dowsett and FDL carried out on the Nyika Plateau are instructive (Dowsett and Dowsett-Lemaire 1986): following the translocation of 43 colour-ringed birds of II species from one area of forest patches to another $6 \mathrm{~km}$ distant, all but two species (Starred Robin and some of the Malawi Batises) failed to return, leaving an empty niche. In most of these nine species, territorial replacements took from a few days to several weeks or a year, but in two of them (some of the Malawi Batis and one of two territories of White-tailed Crested Flycatcher Elminia albonotata) territories were still not re-occupied almost three years later, despite this being in a valley only slightly hidden by grassy ridges, next to other hollows or small valleys with similar forest patches only 0.5-1 km distant (see map in Dowsett and Dowsett-Lemaire 1986).

\section{Population dynamics of forest birds}

One factor putting tropical birds at risk is the slow turn-over of the populations. Adults tend to be long-lived and produce few young in a short breeding season. They are normally single-brooded, lay small clutches and some territorial passerines may not even breed each year (examples from the Nyika can be found in Dowsett-Lemaire 1985). Well-monitored samples of such territorial species as White-chested Alethe, Starred Robin, Olive-flanked Robin Chat Cossypha anomala and Malawi (Cape) Batis over three years showed annual mortality rates of only $13-22 \%$ (Dowsett 1985). A colour-ringed male Yellow-streaked Greenbul reached the age of at least 15 years, on the Nyika. Olive Sunbirds ringed on the slopes of Zomba Mountain have been re-trapped aged 12 and 15 years old (RDM). This great potential longevity is now well recognized among tropical passerines. For example, Hanmer (1989) gave minimum figures of 10-13 years for no fewer than 17 species in southern Malawi and a useful review of this topic was published by Peach et al. (2001).

While there are significant numbers of non-breeding floaters in about half the forest bird species studied on the Nyika Plateau (Dowsett-Lemaire 1985: 142), we have no evidence for the other half, nor from areas with smaller or more isolated forests. Observations of Namuli Apalis at Mabu, Olive Thrush at Namuli, African Hill Babbler on Mangochi Mountain, and translocation experiments on the Nyika give some examples of species where there does not appear to be a surplus, and we believe that extreme care should be taken by collectors in the case of very isolated populations.

\section{Collecting birds in the breeding season}

In some species large numbers of birds have been taken in the breeding season. Breeding seasons of montane forest birds have been well studied in Malawi and are relatively short (Dowsett and Dowsett-Lemaire 1984, with more data presented in Dowsett-Lemaire and Dowsett 2006). Starred Robins breed from September to January, mainly October-December (94\% of clutches laid, $n=282$ ); 65 birds were taken in the Misuku Hills and 21 on the Nyika in October-November, thus at the peak of breeding, and 36 at Ntchisi in late September to early October. The sample of Starred Robins collected in Mugesse Forest in 2003 includes 28 females, of which two were about to lay and two others were said to have a brood patch. In R.J. Dowsett's (pers. comm. and Dowsett 1982) field experience of this species, more females than this that were mist-netted in OctoberNovember would have been at the incubation or nestling stages, thus presenting brood patches of varying appearance, something the collectors apparently did not note, while a few non-breeding adults ("floaters" without a territory) would be inactive. Thus, of 30 adult females mist-netted on the Nyika Plateau in the months of October-November 1979-1981 (most of which were known, colour-ringed individuals), 19 were breeding (pre-laying, laying, brooding eggs or chicks, or with fledglings) and 11 were inactive - either they had not yet laid or they were part of the nonbreeding surplus. 
Yellow-streaked Greenbuls lay in Malawi from September-January $(n=26)$, and the 31 birds taken at Ntchisi were obtained in late September-October. Cabanis's Greenbuls lay from OctoberFebruary $(n=12)$, and all 31 birds collected in 2003-2005 were taken from late September to November. All 26 Stripe-cheeked Greenbuls taken in the Misuku Hills in 2003 were collected in September-October, and 27 birds at Ntchisi in 2005 in late September-October. They lay at least in September-October $(n=8)$, and from a larger sample available for its close relative the Eastern Mountain Greenbul (laying from August to November, $n=76$ ), one can assume that most Stripecheeked Greenbuls were indeed taken in the breeding season. Other examples include Forest Batis, with (in 2003) all 26 birds collected in October-November (they lay at least in SeptemberOctober, $n=6$; and a much larger sample available for its ecological equivalent, the Malawi Batis, shows the main season to be September-December $-94 \%$ of clutches laid, $n=195$ ). In all of these species some females collected by FMNH were indeed noted as preparing eggs or were laying (e.g. two of 12 Yellow-streaked Greenbuls, three Cabanis's Greenbuls, at least four Stripe-cheeked Greenbuls, and three out of eight female Forest Batises). As for the Starred Robin, we suspect that more females would have been at more advanced stages of breeding and that this was not (or could not be) noted. Many or most of the adult males collected were sexually active; however, the size of gonads in males is far less instructive as to the precise stage of the breeding cycle. The first collecting expedition to the Nyika Plateau in June-July 2004 did not coincide with the breeding season for most species, but it did for Greater Double-collared Sunbird (laying from February to August) and Bronze Sunbird (laying in February-March and June-July, during mass flowering of two Leonotis species; Dowsett-Lemaire 1989b).

We consider that collecting birds in the breeding season results in an unnecessary loss to the population and is unethical. Males in all of these species also take part in parental duties, and removal of males in the breeding season should in theory be equally damaging for the fate of the brood. Montane forest birds are usually single-brooded and lay few eggs, but breeding success is generally high (Dowsett-Lemaire 1985); therefore the collection of breeding birds, unless very limited in scope, will likely have a long-term effect on populations.

\section{Collecting in wildlife and forest reserves}

While some of the bird species collected may be locally common, we can see no justification in taking such numbers in wildlife or forest reserves which were primarily set up for their protection. Forest guards (e.g. at Mugesse) and tour guides (Nyika, Mulanje) have expressed dismay in seeing birds killed in their hundreds (pers. comm. to eye-witnesses). Staff in wildlife and other reserves have normally been trained to believe that they are there to protect the wildlife, including birds. Collectors who operate on a large scale and don't even hesitate to take over the main tourist camp in some wildlife reserves (e.g. Bua Camp in Nkhotakota) set a bad example for the local wardens and may discourage them in respect of their anti-poaching activities - their job is difficult enough, and more support is needed, rather than an example going in the opposite direction. People living in the vicinity may also be influenced by the activities of foreigners or members of the National Museum who help themselves to the local resources in this way.

Finally, should collecting in official reserves be authorised for certain species with restricted range, when these reserves represent their last refuges? Examples include Green Barbet in the Misuku Hills Forest Reserve, White-winged Starling in Vwaza Marsh Wildlife Reserve and Churring Cisticola in the Nyika National Park.

\section{Education of conservation biologists}

These activities may also give the wrong idea to young conservation biologists, who may think that collecting birds remains the main line of scientific enquiry today. Instead they are not getting much of a training in field identification skills (including bird vocalisations), in the techniques required to evaluate populations and their turn-over, the potential mobility of forest birds, and 
much else relevant to their conservation. The loss of forest habitat in southern Malawi is such an acute problem that one would have liked to have seen instead the National Museum taking part in local education initiatives to try and save some of the small forest reserves under pressure.

\section{Discussion}

Remsen (1995) presented a fairly extensive summary of arguments in favour of continued collecting of bird specimens. But he strongly emphasised that the proper unit of conservation is the population and that the number of individuals collected "should be reduced for studies of populations of small, isolated fragments of habitats in which over-collecting might drastically reduce a population" (p. 167). This argument was developed further by Collar (2000), who in addition examined the problems posed by (nationally or locally) threatened species and the collection of birds in reserves. Collar (2000) proposed a number of guidelines and numerical adjustments (his Table 3 ) in the case of isolated populations. These guidelines do not seem to have been followed in recent years in Malawi. Thus, even for a "frequent" species like Yellow-streaked Greenbul at Ntchisi (falling most probably into the category of 25-100 birds $\mathrm{km}^{-2}$ ), the number of birds taken should not exceed three (column C of Table 3 ) for a study area of 100 ha, including birds shot and not retrieved. As this bulbul of the mid-stratum is not easily caught in mist-nets, shotguns would need to be used with inevitable loss of wounded or lost birds. In a forest like Ntchisi, only 250 ha in size and greatly isolated from other forests in the country, the number of Yellow-streaked Greenbuls taken in one breeding season (30), not accounting for lost specimens, is clearly far above the recommended safeguards. Other examples among birds collected at Ntchisi or elsewhere tell the same story.

Another important recommendation of Collar (2000), which we fully endorse here, is that the "collection of species in protected areas should as a general rule be avoided, even when permitted by the authorities, but otherwise should be undertaken with the utmost discretion (including the minimal use of shotguns) and only after full consultation of all local staff and education workers." These suggestions have unfortunately been ignored in Malawi: intensive collecting has taken place in some of the most popular reserves (such as the Nyika Plateau and Mount Mulanje), and conservation organisations were not consulted, e.g. the Nyika-Vwaza Conservation Trust, the Mount Mulanje Conservation Trust, or the Wildlife and Environmental Society of Malawi (WESM). Moreover, the way some collectors have been operating (as in the main tourist camp of Nkhotakota W.R.) is anything but discreet and unlikely to endear them to tourists and conservationists.

In short, given the patchy distribution or isolation of populations of forest birds, the slow turnover rate of these populations and the important scientific and educative role that official reserves should play, we contend that numbers of birds taken in Malawi's small forest reserves by foreign as well as national institutions should be considerably reduced in any future expeditions. Some species should be strictly protected and no longer collected, as suggested for African Pitta, Green Barbet and others in the examples above. A paper by Winker et al. (2010), of which J. Bates is a co-author, has indeed stressed the importance of taking into account the life history characteristics of species collectors intend to sample. J. Bates (in litt. to FDL 9 July 2008) contends that his staff adheres to "recommendations about scientific collecting put forward by noted avian conservation biologists such as Nigel Collar", but we consider this statement does not reflect the facts.

Moreover, the National Museum of Malawi, in collaboration with FMNH, proposed the continued collection of birds until at least 2013 (Kaliba et al. n.d.): areas targeted include the Nyika National Park, Vwaza Marsh Wildlife Reserve, the South Viphya Forest Reserve, parts of the Shire Valley and Mount Mulanje Forest Reserve. Reasons put forward include the documentation of bird distribution, as, before the year when their collaboration started "most of the bird specimens from Malawi were old with relatively little data (sic) (often with no more than "Nyasaland" noted for the locality)". This argument is untrue, insofar as labels for the great majority of specimens collected in the 19th and 2oth centuries bear clear indications of locations, even among the 
oldest collections (as by Alexander Whyte). They were also detailed at length in publications. This is evident to anyone reading the chapter devoted to the history of ornithology in Malawi in Dowsett-Lemaire and Dowsett (2006: 4-12). In any case, bird distribution can be documented more efficiently and quickly by visual observations complemented, if required, by photographic evidence and tape-recordings. The extensive collections obtained by FMNH in a number of forest and wildlife reserves in the 2000 s have not, after all, added a single locality record for any rain forest species - with the possible exception of Kenrick's Starling Poeoptera kenricki (Misuku, June 2007), so far undocumented in the literature.

Kaliba et al. (n.d.) also claim that collecting will provide much new information on breeding seasonality, because examination of gonad size "helps precisely delineate breeding seasons". This is, as explained above, largely untrue, except during the few days when a female is (pre-) laying. More information can be obtained by visual observations of the nesting behaviour of birds, combined, as the case may be, with the examination of brood patches of females mistnetted and released (Dowsett and Dowsett-Lemaire 1984). The aspect of a brood patch varies according to the stages of the breeding cycle, being watery and fat during incubation, becoming leaner and wrinkled at the nestling stage, etc. (FDL, RDM pers. obs.). It is usually easy to find evidence of feeding activity of nestlings or fledglings, without searching for nests as such, a time-consuming activity that can also be detrimental to the birds through increased predation (Dowsett-Lemaire 1985: 138).

Kaliba et al. (n.d.) insist on the importance of continuing to collect for analysing internal parasites: while identifying new species of parasites may indeed be of interest to invertebrate biologists and to understand the history of host-parasite co-evolution, these proposals have not paid sufficient attention to the dangers faced by small bird populations submitted to such investigations. Indeed, why choose Malawi's small reserves for such a study?

The study of molecular systematics of isolated populations remains one of their priorities, and no doubt one of the more interesting. But we would query their statement that "for many research questions, tissues are not available in other collections" and therefore, they need to collect more. Why not make use of some of the thousands of well-preserved specimens from Malawi's forests in several international institutions, with about half of them in the Natural History Museum in UK? The necessity of maximizing the use of museum material already available is a point also stressed by Collar (2000: guideline 5, p. II). To give just one example, Yellow-streaked Greenbul of the race alfredi was obtained by Con Benson alone from the following localities, from north to south (it is absent from the Misuku Hills): Mafinga Mountains, Nyika Plateau (eastern escarpment), North Viphya Plateau (Uzumara and Chimaliro Mountains), South Viphya Plateau and Ntchisi Mountain (Benson 1940-4I). This covers most of the range of this form in Malawi (Dowsett-Lemaire and Dowsett 2006). If this material is not sufficient, why not collect blood samples of live birds (which can then be released unharmed), as this method is considered by some geneticists as more useful than the analysis of solid tissue?

In 2008 Hazell Thompson (then the Africa Regional Director of BirdLife International) wrote to the Directors of the Department of National Parks and Wildlife (DNPW) and the Department of Forestry, expressing concern at the seemingly high numbers of birds being collected by museums in Malawi. A similar letter sent to the Director of DNPW, Leonard Sefu, by RDM in September 2008 provoked an encouraging reply assuring that restrictions would be imposed on unnecessary bird collecting. This, however, has not happened. The supervision and checking by the authorities of what takes place in the field after collecting permits have been issued leaves much to be desired. FRIM (the Forestry Research Institute of Malawi, responsible for issuing collecting permits for forest reserves) has not received any reports of collections since 2001 (as verified by JGMW at their headquarters in Zomba), even though the FRIM collecting licence clearly states that a list of all specimens must be submitted to them within three weeks. Potiphar Kaliba (to whom permits have been issued on an annual basis) has not sent any reports to DNPW either (as checked by LR). The only report held by DNPW is that for the Vwaza Marsh expedition of 2009, and this is only because one of their own field staff sent a list of species 
collected (without any indication of numbers). Since P. Kaliba left the National Museum, staff in charge of the bird collections have not had access to those lists either.

Ms Tiwonge Mzumara (conservation biologist) proposed, in a letter sent to Sam Kamoto (Secretary of WESM) on 31 January 2010, setting up a meeting with DNPW and FRIM to discuss the possible role of WESM in controlling collecting requests. A meeting finally took place between J. Bates, Museum staff, one member of Mount Mulanje Conservation Trust and two members of WESM (but none from DNPW, FRIM nor Nyika-Vwaza Conservation Trust) in Blantyre on 16 March 2011. This was organized to air the problems and discuss possible solutions and ways of controlling the way that wild birds have been exploited in recent years. The fact that details of the collections (outside the years 2003-2005) were not available to the public until 2013 has been a major problem.

We hope that this paper will prompt international conservation organisations to take an interest and react to some of the questions raised here. FMNH and other Western museums have been collecting elsewhere in Africa, and in some countries numbers taken also appear to be excessive. As an example, a single expedition by FMNH to the Ruwenzori Mountains Forest Reserve of Uganda in 1990-1991 (just months before the reserve became a national park) obtained thousands of birds, including, e.g. 93 Eastern Mountain Greenbuls, 91 Blue-headed Sunbirds Nectarinia alinae, 122 Regal Sunbirds Nectarinia regia, etc. (http://www.fieldmuseum.org/research_collections/ zoology/collections_birds.htm).

The size of habitat islands in Africa is decreasing almost everywhere and even much larger patches of forest (as on Mabu Mountain in Mozambique) than the small reserves of Malawi may have tiny populations of some species. Large-scale collecting should be a thing of the past and institutions such as the FMNH should be showing the lead, instead of adding to the list of everincreasing threats to the survival of bird populations.

\section{Supplementary Material}

The online supplementary materials for this article can be found at journals.cambridge.org/bci.

\section{Acknowledgements}

We thank Nigel Collar and four anonymous referees for constructive comments on a draft.

\section{References}

Benson, C. W. (1940-41) Further notes on Nyasaland birds (with particular reference to those of the Northern Province). Ibis (14) 4: 257-298, 387-433, 583-629; 5: $1-55$.

Benson, C. W. and Benson, F. M. (1977) The birds of Malawi. Limbe, Malawi: Montfort Press.

BirdLife International (2008) Threatened birds of the world. CD-ROM. Cambridge, UK: BirdLife International.

Collar, N. (200o) Collecting and conservation: cause and effect. Bird Conserv. Internatn. 10: $1-15$.

Dowsett, R. J. (1982) The population dynamics and seasonal dispersal of the Starred Robin Pogonocichla stellata. M.Sc. thesis. Pietermaritzburg: University of Natal.
Dowsett, R. J. (1985) Site fidelity and survival rates of some montane forest birds in Malawi, south-central Africa. Biotropica 17: 145-154.

Dowsett, R. J. and Dowsett-Lemaire, F. (1984) Breeding and moult cycles of some montane forest birds in south-central Africa. Rev. Ecol. (Terre et Vie) 39: 89-111.

Dowsett, R. J. and Dowsett-Lemaire, F. (1986) Homing ability and territorial replacement in some forest birds in south-central Africa. Ostrich 57: 25-31.

Dowsett, R. J. and Hunter, N. D. (1980) Birds and mammals of Mangochi Mountain, Malawi. Nyala 6: 5-18.

Dowsett-Lemaire, F. (1985) Breeding productivity and the non-breeding element in some montane forest birds in Malawi, south-central Africa. Biotropica 17: 137-144. 
Dowsett-Lemaire, F. (1989a) Ecological and biogeographical aspects of forest bird communities in Malawi. Scopus 13: 1-80.

Dowsett-Lemaire, F. (1989b) Food plants and the annual cycle in a montane community of sunbirds (Nectarinia spp.) in northern Malawi. Tauraco 1: 167-185.

Dowsett-Lemaire, F. (2010) Further ornithological exploration of Namuli and Mabu Mountains (northern Mozambique), and the urgent need to conserve their forests. Bull. Afr. Bird Club 17: 159-177.

Dowsett-Lemaire, F. and Dowsett, R. J. (2006) The birds of Malawi. Liège: Tauraco Press and Aves.

Dowsett-Lemaire, F., Dowsett, R. J. and Dyer, M. (2001) Malawi. Pp. 539-555 in L. D. C. Fishpool and M. I. Evans, eds. Important bird areas in Africa and associated islands. Newbury and Cambridge, UK: Pisces Publications and BirdLife International.

Fry, C. H., Keith, S. and Urban, E. K. (2000) The birds of Africa. Vol. VI. London, UK: Academic Press.

Hanmer, D. B. (1989) The end of an era - final longevity figures for Nchalo. Safring news 18: 19-30.

\section{FRANCOISE DOWSETT-LEMAIRE* \\ Le Pouget, 30440 Sumène, France.}

JOHN G. M. WILSON

WESM, P.O. Box 537, Zomba, Malawi.

ROBERT D. MEDLAND

Past Chairman, WESM. Camway Cottage, Cameley, BS39 5 AJ, UK.

\section{LIZANNE ROXBURGH}

Endangered Wildlife Trust, Post Bag XII, Modderfontein, 1645, Johannesburg, South Africa.

*Author for correspondence; email:dowsett@aol.com
Kaliba, P. M. S., Mazibuko, L. M. S., Hackett, S., Gnoske, T., Bates, J., Willard, D. and Weckstein, J. (n.d., c. 2009) Documenting the distribution, habitat associations and genetic makeup of vertebrate and vertebrate parasites of Malawi. Report from the National Museum, Blantyre.

Melo, M. and Fuchs, J. (2008) Phylogenetic relationships of the Gulf of Guinea Alcedo kingfishers. Ibis 150: 633-639.

Peach, W. J., Hanmer, D. B. and Oatley, T. B. (2001) Do southern African songbirds live longer than their European counterparts? Oikos 93: 235-249.

Remsen, J. V. (1995) The importance of continued collecting of bird specimens to ornithology and bird conservation. Bird Conserv. Internatn. 5: 145-180.

Stattersfield, A. J., Crosby, M. J., Long, A. J. and Wege, D. C. (1998) Endemic Bird Areas of the world. Priorities for biodiversity conservation. Cambridge, UK: BirdLife International.

Winker, K., Reed, J. M., Escalante, P., Askins, R. A., Cicero, C., Hough, G. E. and Bates, J. (2010) The importance, effects, and ethics of bird collecting. Auk 127: 690-695.

Received 17 February 2012; revision accepted 1o December 2013; Published online 24 April 2015 